Prepared in cooperation with Bureau of Reclamation

\title{
Detection Probability of an In-Stream Passive Integrated Transponder (PIT) Tag Detection System for Juvenile Salmonids in the Klamath River, Northern California, 2011
}

Open-File Report 2012-1001

U.S. Department of the Interior U.S. Geological Survey 
Cover: Photograph showing upstream view of one of the pass-by antennas at Klamath River kilometer 252.7, northern California, August 25, 2010. (Photograph taken by Brian Hayes, U.S. Geological Survey.) 


\section{Detection Probability of an In-Stream Passive Integrated Transponder (PIT) Tag Detection System for Juvenile Salmonids in the Klamath River, Northern California, 2011}

By John W. Beeman and Brian Hayes, U.S. Geological Survey; and Katrina Wright, U.S. Fish and Wildlife Service

Prepared in cooperation with the Bureau of Reclamation

Open-File Report 2012-1001 


\section{U.S. Department of the Interior \\ KEN SALAZAR, Secretary}

\section{U.S. Geological Survey \\ Marcia K. McNutt, Director}

U.S. Geological Survey, Reston, Virginia: 2012

For more information on the USGS-the Federal source for science about the Earth, its natural and living resources, natural hazards, and the environment, visit http://www.usgs.gov or call 1-888-ASK-USGS.

For an overview of USGS information products, including maps, imagery, and publications, visit http://www.usgs.gov/pubprod

To order this and other USGS information products, visit http://store.usgs.gov

Suggested citation:

Beeman, J.W., Hayes, B., and Wright, K., 2012, Detection probability of an in-stream passive integrated transponder (PIT) tag detection system for juvenile salmonids in the Klamath River, northern California, 2011: U.S. Geological Survey Open-File Report 2012-1001, 14 p.

Any use of trade, product, or firm names is for descriptive purposes only and does not imply endorsement by the U.S. Government.

Although this report is in the public domain, permission must be secured from the individual copyright owners to reproduce any copyrighted material contained within this report. 


\section{Contents}

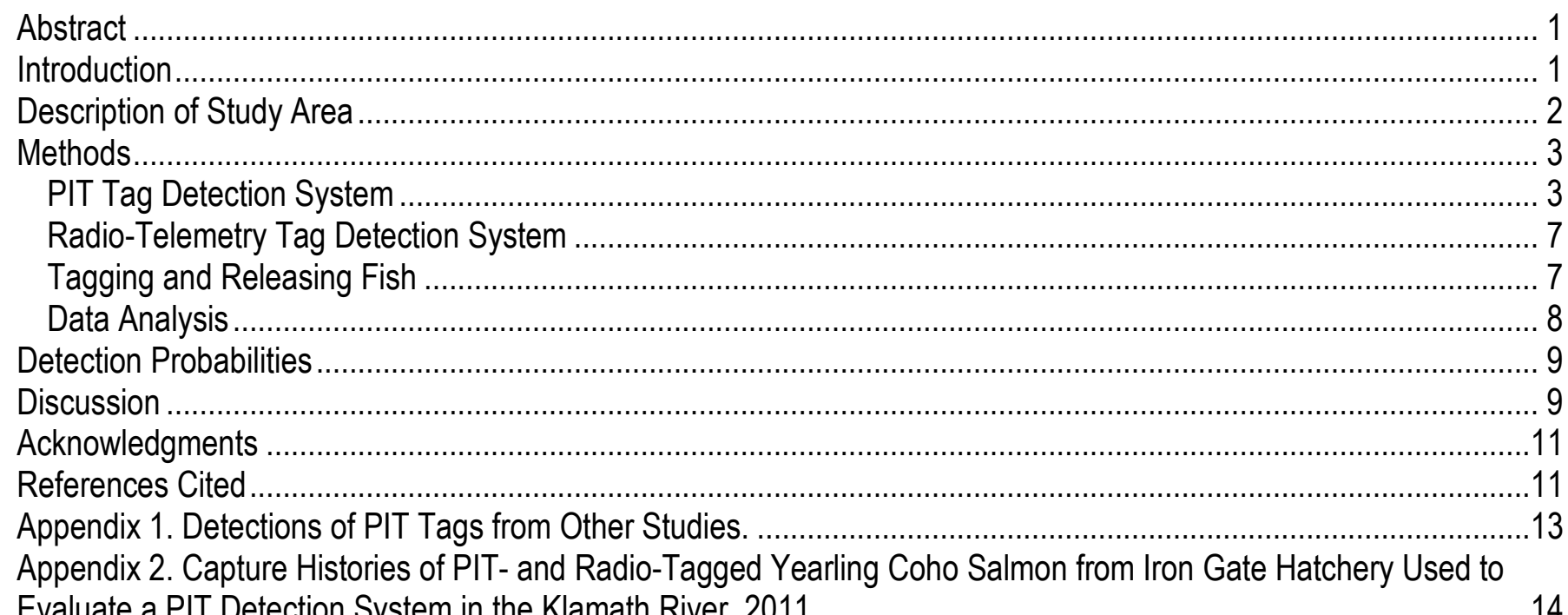

\section{Figures}

Figure 1. Map of the study area of the Klamath River in northern California

Figure 2. Upstream view of one of the pass-by antennas at Klamath River kilometer 252.7, northern California, August 25, 2010

Figure 3. Graph of the discharge downstream of Iron Gate Dam between the time of PIT tag detection system installation and the end of the study period, Klamath River, northern California

Figure 4. Upstream views of the pass-through antennas on July 27 and June 1, 2011, Klamath River, northern California

Figure 5. Upstream view of the PIT detection system mounted in the frame net at Klamath River kilometer 271.2, northern California. 


\section{Conversion Factors and Datum}

\section{Conversion Factors}

Inch/Pound to SI

\begin{tabular}{ccc}
\hline Multiply & By & To obtain \\
\hline & Flow rate & \\
\hline cubic foot per second $\left(\mathrm{ft}^{3} / \mathrm{s}\right)$ & 0.02832 & cubic meter per second $\left(\mathrm{m}^{3} / \mathrm{s}\right)$ \\
\hline
\end{tabular}

SI to Inch/Pound

\begin{tabular}{lll}
\hline \multicolumn{1}{c}{ Multiply } & By & \multicolumn{1}{c}{ To obtain } \\
\hline centimeter (cm) & Length & \\
millimeter (mm) & 0.3937 & inch (in.) \\
meter (m) & 0.03937 & inch (in.) \\
kilometer (km) & 3.281 & foot (ft) \\
\hline & 0.6214 & mile (mi) \\
\hline liter (L) & Volume & \\
liter (L) & 33.82 & ounce, fluid (fl. oz) \\
liter (L) & 2.113 & pint (pt) \\
liter (L) & 1.057 & quart (qt) \\
cubic meter (m ${ }^{3}$ ) & 0.2642 & gallon (gal) \\
milligram per liter (mg/L) & 264.2 & gallon (gal) \\
& 0.00000058 & pounds per gallon (lb/gal) \\
\hline & & \\
\hline gram (g) & Mass & \\
\hline
\end{tabular}

Temperature in degrees Celsius $\left({ }^{\circ} \mathrm{C}\right)$ may be converted to degrees Fahrenheit $\left({ }^{\circ} \mathrm{F}\right)$ as follows: ${ }^{\circ} \mathrm{F}=\left(1.8 \times{ }^{\circ} \mathrm{C}\right)+32$.

Datum

Horizontal coordinate information is referenced to the North American Datum of 1983 (NAD 83). 


\title{
Detection Probability of an In-Stream Passive Integrated Transponder (PIT) Tag Detection System for Juvenile Salmonids in the Klamath River, Northern California, 2011
}

By John W. Beeman and Brian Hayes, U.S. Geological Survey; and Katrina Wright, U.S. Fish and Wildlife Service

\begin{abstract}
A series of in-stream passive integrated transponder (PIT) detection antennas installed across the Klamath River in August 2010 were tested using tagged fish in the summer of 2011. Six pass-by antennas were constructed and anchored to the bottom of the Klamath River at a site between the Shasta and Scott Rivers. Two of the six antennas malfunctioned during the spring of 2011 and two passthrough antennas were installed near the opposite shoreline prior to system testing. The detection probability of the PIT tag detection system was evaluated using yearling coho salmon implanted with a PIT tag and a radio transmitter and then released into the Klamath River slightly downstream of Iron Gate Dam. Cormack-Jolly-Seber capture-recapture methods were used to estimate the detection probability of the PIT tag detection system based on detections of PIT tags there and detections of radio transmitters at radio-telemetry detection systems downstream. One of the 43 PIT- and radio-tagged fish released was detected by the PIT tag detection system and 23 were detected by the radio-telemetry detection systems. The estimated detection probability of the PIT tag detection system was 0.043 (standard error 0.042). Eight PIT-tagged fish from other studies also were detected. Detections at the PIT tag detection system were at the two pass-through antennas and the pass-by antenna adjacent to them. Above average river discharge likely was a factor in the low detection probability of the PIT tag detection system. High discharges dislodged two power cables leaving 12 meters of the river width unsampled for PIT detections and resulted in water depths greater than the read distance of the antennas, which allowed fish to pass over much of the system with little chance of being detected. Improvements in detection probability may be expected under river discharge conditions where water depth over the antennas is within maximum read distance of the antennas. Improvements also may be expected if additional arrays of antennas are used.
\end{abstract}

\section{Introduction}

Passive integrated transponder (PIT) tags commonly are used to study fish, including their movements and survival (Williams and others, 2001; Hewitt and others, 2010). PIT tags are radio frequency identification tags that transmit an alphanumeric code as they pass through the electromagnetic field emitted by a detection antenna (Prentice and others, 1990). PIT tags are useful for various purposes because many types are relatively small (slightly larger than a grain of rice) and are powered by a detection antenna and therefore have a nearly infinite life. However, PIT antennas emit a 
weak electromagnetic field, therefore, the tags must be between about 10 and $100 \mathrm{~cm}$ from the antenna to be detected, depending on the tag and antenna system. PIT-tagged fish in the Klamath River are being used to study juvenile salmonid movements within and among several habitats and tributaries, but most of the antenna systems are located in small tributaries or backwaters where detection probabilities generally are high. PIT detection systems in the mainstem Klamath River would be useful for linking movements of fish tagged in the Klamath River or its tributaries as they move between habitats. The goal of this study was to evaluate the detection probability of an in-stream PIT antenna system in the Klamath River.

\section{Description of Study Area}

The study was conducted in the Klamath River in northern California between the Iron Gate Fish Hatchery and a site slightly upstream of the confluence of the Klamath and Scott Rivers (fig. 1). This section of the Klamath River was chosen for evaluating the PIT detection system because water depth in the main-stem river downstream may be too high for use of PIT systems due to tributary accretions, and there are studies using PIT tags in nearby tributaries, such as the Shasta River (Chris Adams, California Department of Fish and Game, written commun., November 16, 2011).

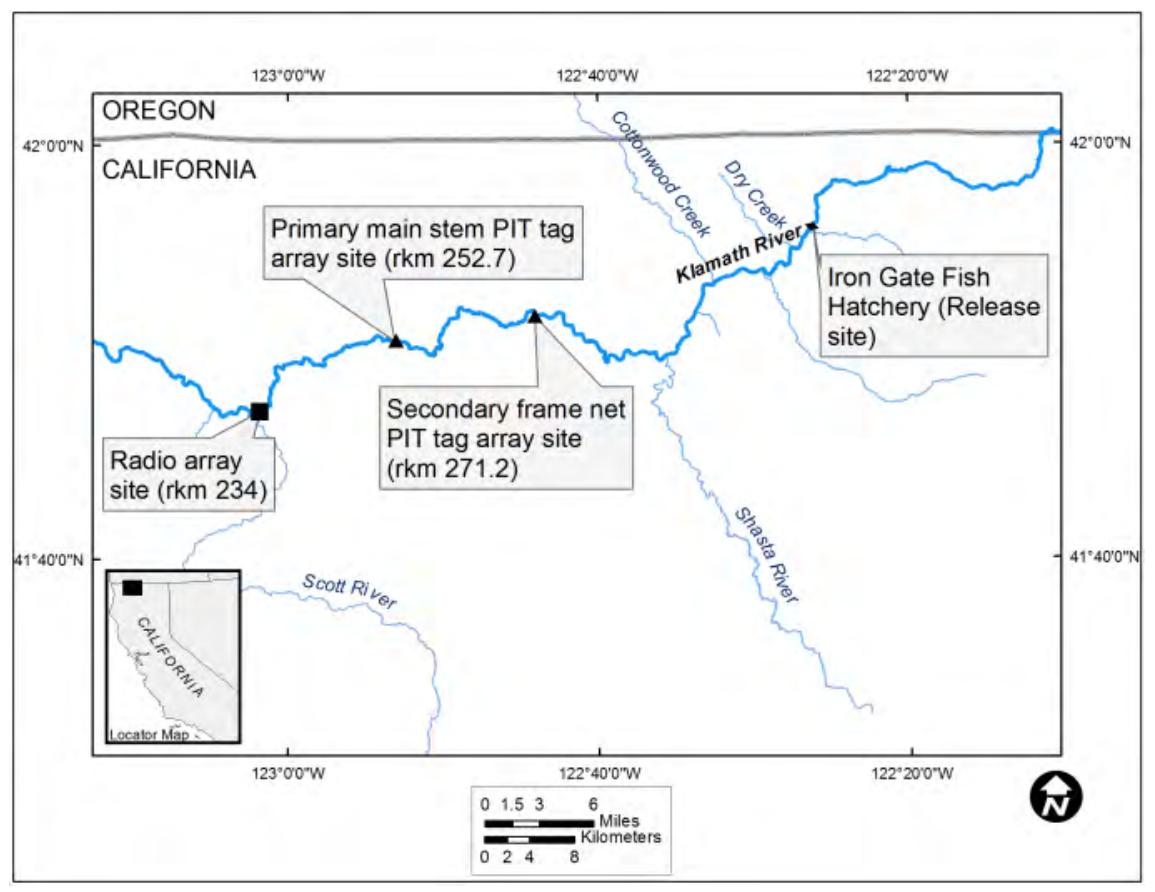

Figure 1. Map of the study area of the Klamath River in northern California. 


\section{Methods}

\section{PIT Tag Detection System}

The primary PIT detection system was a Digital Angel FS1001M multiplexing transceiver and six full-duplex PIT tag antennas at Klamath River kilometer 252.7 from the river mouth. Six $6.1 \times 0.60$ $\mathrm{m}$ PIT tag antennas were constructed and installed in a pass-by orientation (mounted horizontally to the river bottom; Connolly and others, 2008) in late August 2010 when Iron Gate Dam discharge was near the lowest of the year (fig. 2). These antennas spanned the width of the river when installed. Each antenna consisted of wires and electronics housed inside a 10.2-cm diameter polyvinyl chloride pipe and formed a rectangle. At the time of installation, river discharge near Iron Gate Dam was about 1,000 $\mathrm{ft}^{3} / \mathrm{s}$ and gage height was $0.74 \mathrm{~m}$ (USGS gaging station 11516530). Water depth at the PIT array site ranged between 0.6 and $1.25 \mathrm{~m}$ during installation. The antennas were attached to the river bottom in a $1 \times 6$ array perpendicular to flow to span as much of the $42.6 \mathrm{~m}$ wide river channel as possible (six antennas laid end-to-end across the river). Antenna 1 was located nearest the transceiver on river left (facing downstream) and each subsequent antenna was installed extending out from the previous antenna towards the opposite bank. Each antenna was secured to the river bottom using about ten $10-20 \mathrm{~cm}$ earth anchors driven $1.5 \mathrm{~m}$ below the cobble substrate leaving a loop at the surface for attachment.

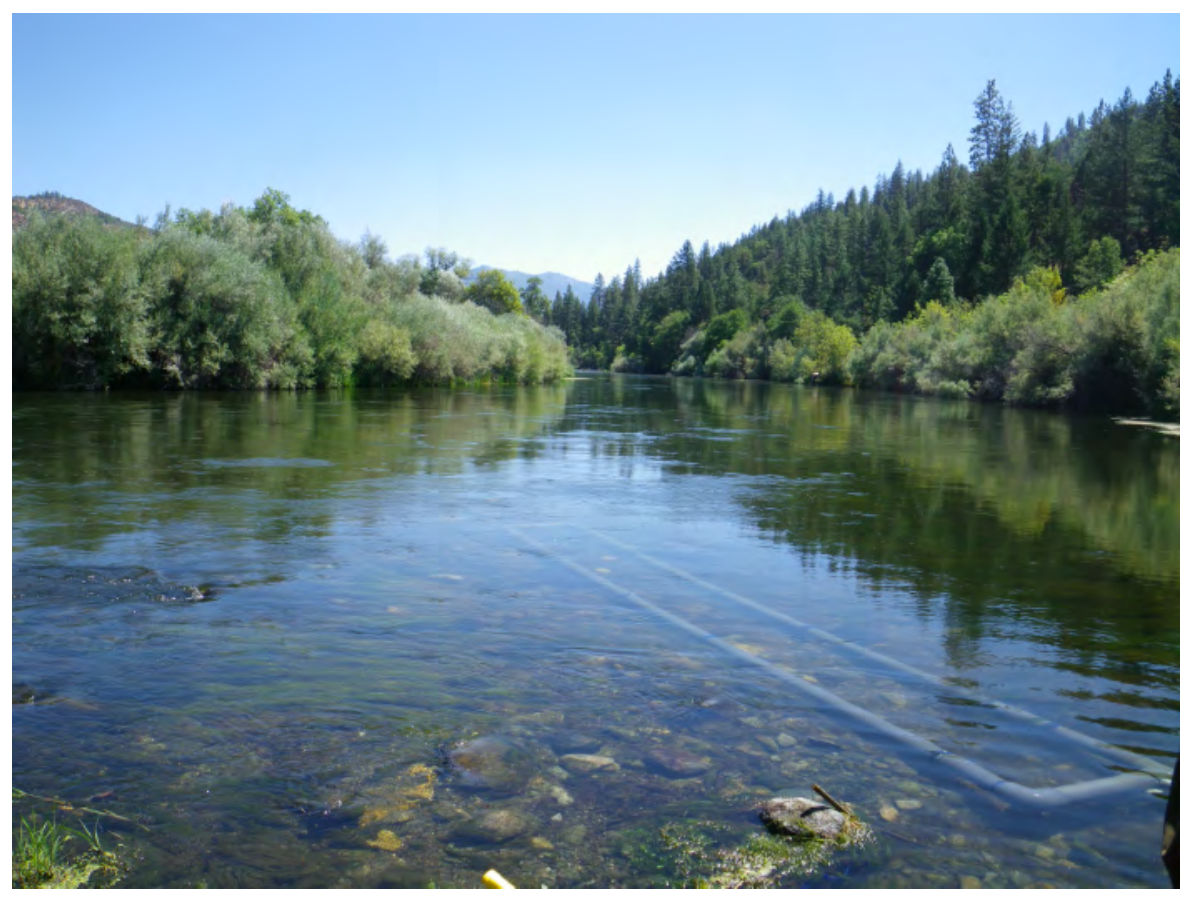

Figure 2. Upstream view of one of the pass-by antennas at Klamath River kilometer 252.7, northern California, August 25, 2010. 
Once installed, the PIT tag detection system was operated for several weeks for testing and evaluating before it was turned off for the winter. On March 9, 2011, the PIT transceiver and solar power were re-installed for more evaluation prior to release of the radio- and PIT-tagged study fish. During this testing period, data were downloaded periodically to examine antenna diagnostics. These downloads provided information that indicated two antennas farthest from the receiver were no longer functioning effectively, presumably due to high flows and debris disconnecting the power cable or dislodging an antenna in mid-April 2011 (fig. 3). High river discharge and water depth also prevented these two antennas from being repaired or replaced. Two additional $3 \times 0.91 \mathrm{~m}$ antennas were installed in a pass-through (upright) orientation in a backwater area adjacent to the original PIT tag antennas to increase coverage during high river discharge (fig. 4; Zydlewski and others, 2006). Antennas were numbered 1-6 across the river beginning at river left shore near the receiver, thus antenna numbers 1 and 2 were pass-through antennas and antennas 3-6 were pass-by antennas. The damage to the two original antennas farthest from the receiver resulted in approximately $12 \mathrm{~m}$ of the river width without PIT antennas. The revised PIT detection system, consisting of two pass-through and four pass-by antennas, was operational on June 1, 2011, and it functioned continuously until August 10, 2011.

During the initial testing and throughout the intended study period, the antennas were consistently detecting test tags 35-41 cm off the antenna plane on the pass-by antennas. The two passthrough antennas were detecting tags throughout the $3 \mathrm{~m} \times 0.91 \mathrm{~m}$ opening and up to $16 \mathrm{~cm}$ from the outside edges of the opening. Estimated depth at the PIT detection site when the first tagged fish were released from Iron Gate Hatchery was 1.5-1.8 m. Gage height was $1.5 \mathrm{~m}$ and river flow was about 3,000 $\mathrm{ft}^{3} / \mathrm{s}$ at USGS gaging station 11516530 downstream of Iron Gate Dam. River discharge at this gage between August 1 and August 10, 2011, averaged 1,948.1 $\mathrm{ft}^{3} / \mathrm{s}$ and ranged from 904 to 5,620 $\mathrm{ft}^{3} / \mathrm{s}$.

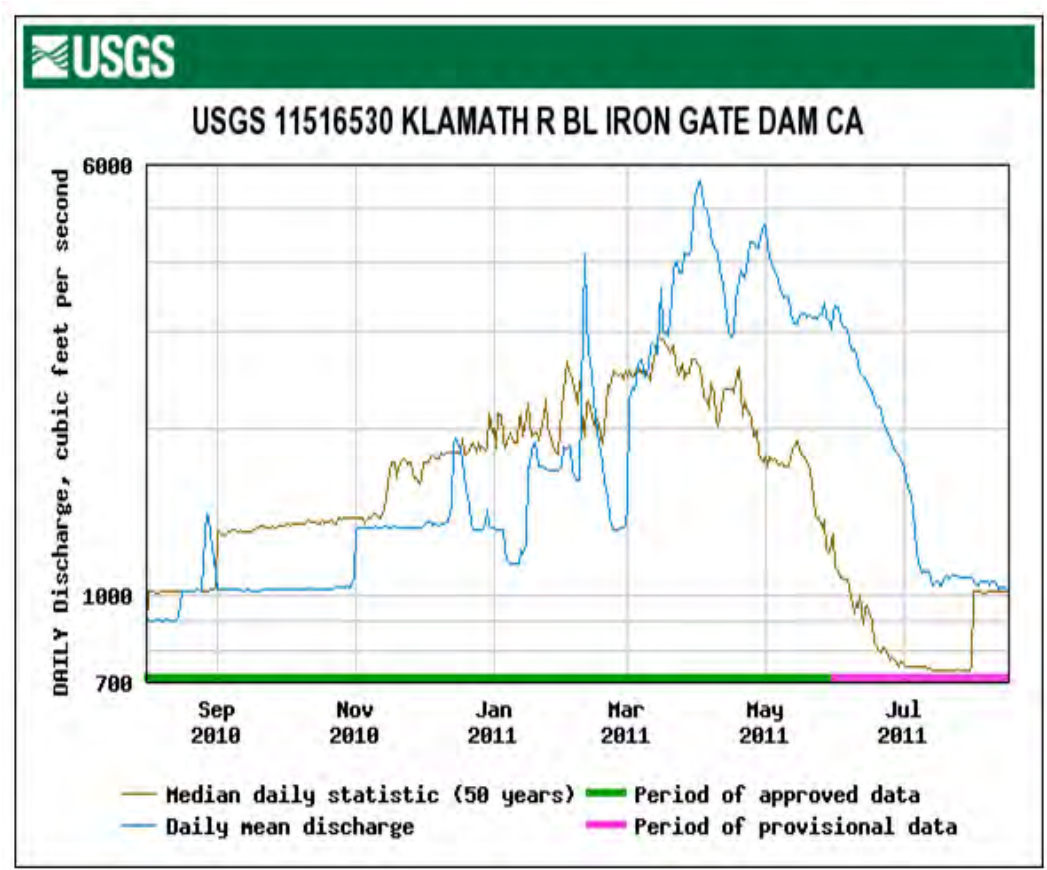

Figure 3. Graph of the discharge downstream of Iron Gate Dam between the time of PIT tag detection system installation and the end of the study period, Klamath River, northern California. Note the high discharge in April 2011 relative to the 50-year record. 

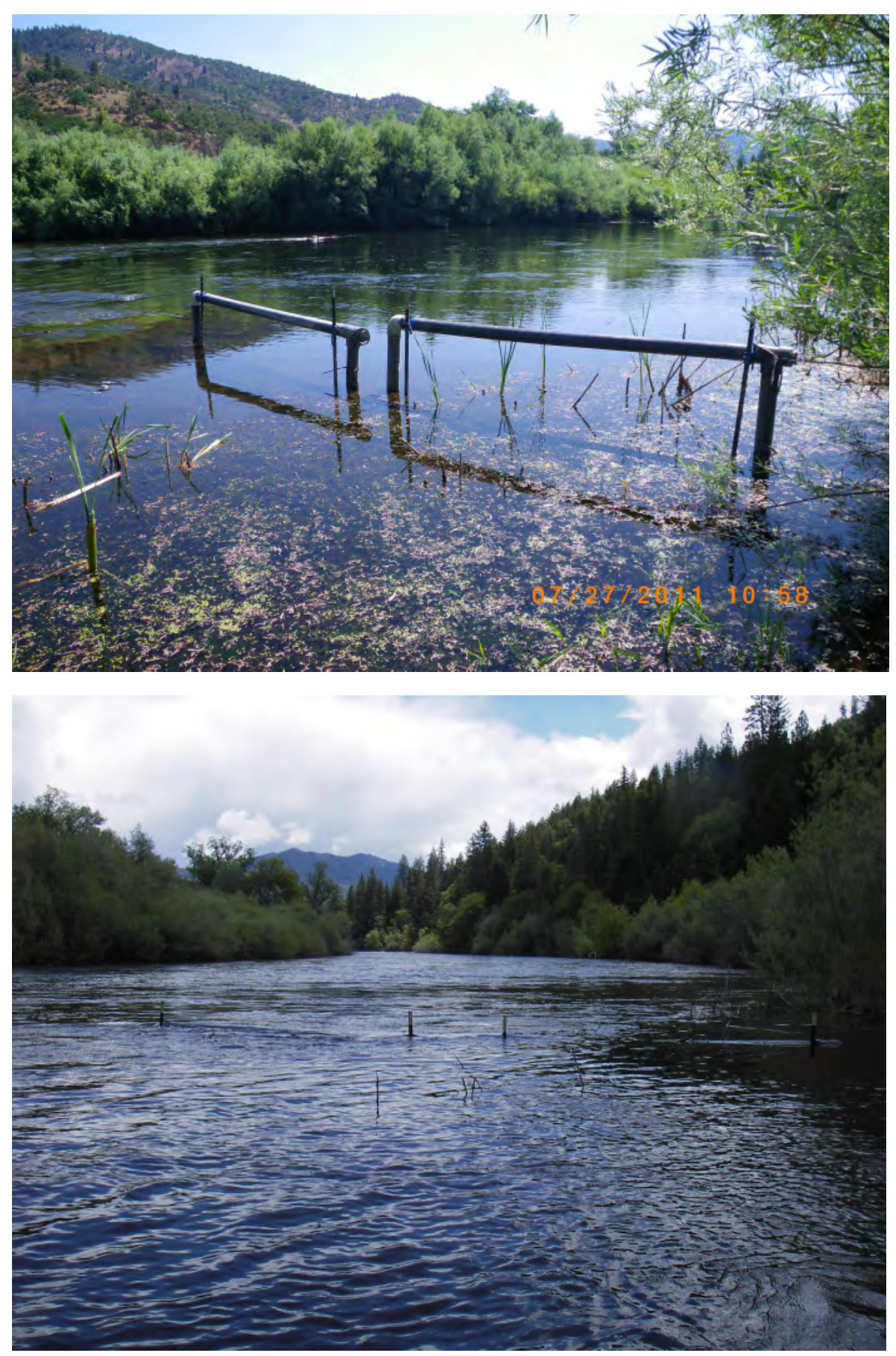

Figure 4. Upstream views of the pass-through antennas on July 27 (top photograph) and June 1, 2011 (bottom photograph), Klamath River, northern California. Average hourly discharges measured at USGS gaging station 11516530 downstream of Iron Gate Dam were 1,090 ft3/s on July 27 and 3,200 ft3/s on June 1, 2011. 
A secondary PIT detection system deployed from a frame net was installed in a flat-water run habitat on the river right at Klamath River kilometer 271.2. A wide-mouthed net was anchored to a 23.1 $\times 1.5 \mathrm{~m}$ metal frame. The wide opening faced upstream and a 15-m net tapered down to a Biomark $0.6 \times$ $0.6 \mathrm{~m}$ waterproof pass-through antenna at the downstream end (fig. 5). A Destron FS2001 transceiver on the right bank recorded tag detections and data were downloaded weekly. This PIT array was operated from June 2 to July 13, 2011, when decreasing water depth made the pass-through trap ineffective.

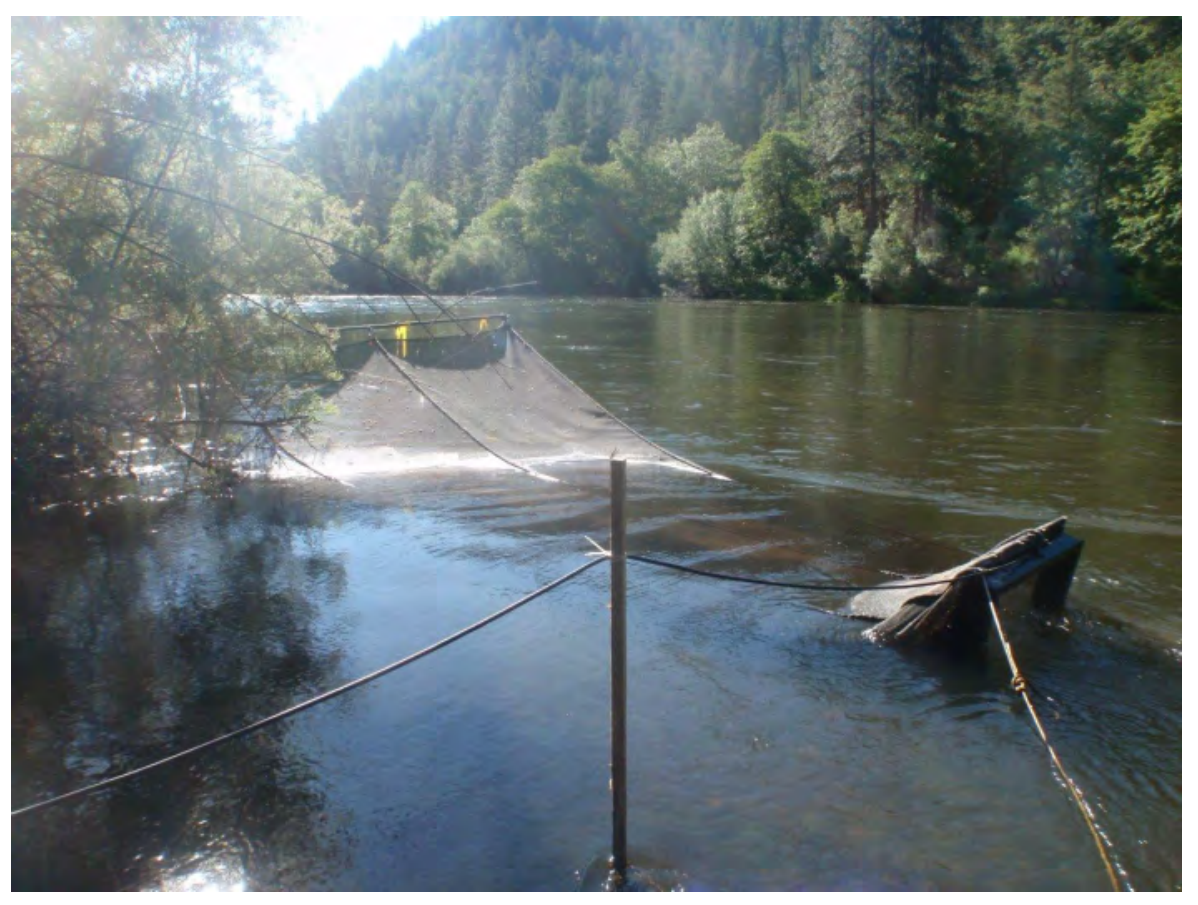

Figure 5. Upstream view of the PIT detection system mounted in the frame net at Klamath River kilometer 271.2, northern California. 


\section{Radio-Telemetry Tag Detection System}

Detections of radio-telemetry tags were based on two independent systems. The systems were installed at Klamath River kilometer 234 upstream of the confluence of the Klamath and Scott Rivers. Each independent system consisted of a solar panel and voltage regulator, 12-volt battery, and a Lotek SRX-400 radio-telemetry receiver receiving radio signals from two 3-element and two 6-element Yagi antennas combined into a single input. The radio receivers sequentially scanned each of three radio frequencies $(164.320,164.480$, and $166.478 \mathrm{MHz})$ for $8.7 \mathrm{~s}$ in a repeating loop. Both systems monitored the same spatial area and were similar in design and location to those used in the studies of juvenile coho salmon migration and survival in 2006-09 (Beeman and Juhnke, 2009). The systems operated continuously from a few days prior to the date of fish release to August 18, 2011, when the systems were removed at the end of the study period.

\section{Tagging and Releasing Fish}

Fish for this study were obtained from the Iron Gate Fish Hatchery located along the Klamath River at river kilometer 310. A total of 43 yearling coho salmon of hatchery origin surgically implanted with radio transmitters and PIT tags were released on June 1 and 2, 2011, 1 day after the tags were surgically implanted. Three additional hatchery coho salmon implanted with only PIT tags were released on June 2, 2011, 1 day after tags were surgically implanted. We used Lotek model NTC-M-2 radio transmitters, which had dimensions of $13 \times 5 \times 3 \mathrm{~mm}$ in size, weighed $0.43 \mathrm{~g}$ in air and $0.29 \mathrm{~g}$ in water, and had a $16 \mathrm{~cm}$ trailing antenna. The expected life of this transmitter using a coded burst rate of $7.8 \mathrm{~s}$ was $46 \mathrm{~d}$, and 24 transmitters of the same specifications tested in 2009 had a mean life of $65.3 \mathrm{~d}$ (range 58.3-69.5 d; John Beeman, U.S. Geological Survey, unpublished data). We used DestronFearing SST full-duplex PIT tags, which had dimensions of $12.5 \mathrm{~mm}$ long $\times 2.1 \mathrm{~mm}$ diameter and weighed $0.10 \mathrm{~g}$ in air. PIT tags do not use a battery and so have an infinite life. The PIT tags operated at a frequency of $134.2 \mathrm{kHz}$.

The size of each fish was recorded immediately prior to tagging. The mean weight of fish before tagging was $59.8 \mathrm{~g}$ [standard deviation $(\mathrm{SD})=23.3$ ] and the mean fork length was $178 \mathrm{~mm}(\mathrm{SD}=24.7)$. The combined weight of the radio transmitter and PIT tag represented 0.89 percent of the mean body weight of the fish and ranged from 0.45 to 3.0 percent of each individual's body weight.

The procedure used to surgically implant the radio transmitters and PIT tags was similar to that used by Adams and others (1998) and previous Klamath River radio-telemetry studies (Stutzer and others, 2006; Beeman and others, 2008; Wright and others, 2011). Before surgery, each fish was anesthetized in a bath of tricaine methanesulfonate (70 mg/L Finquel MS-222, Argent Chemical Laboratories, Redmond, Washington) until loss of equilibrium occurred. A foam pad with a central groove shaped to fit the dorsal surface of a small fish was covered with a chamois soaked in PolyAqua (Novalek, Inc., Hayward, California) and used to support the fish’s body during surgery. Fish were placed ventral side up on the surgical support pad, and the gills were flushed with anesthetic solution (20 mg/L MS-222) for the duration of the surgery through tubing placed in fish's mouth. The mean ( $\pm 1 \mathrm{SD}$ ) time to complete each surgical procedure was 4 min $02 \mathrm{~s}( \pm 26 \mathrm{~s})$. Water temperatures in the hatchery tank, bait tank used to hold fish after surgery, and the Klamath River nearby ranged from 9.98 to $10.74{ }^{\circ} \mathrm{C}$ and dissolved oxygen was 89.2 percent or greater during tagging, holding, and release. 
Surgical tools and equipment were disinfected according to the procedures described by Summerfelt and Smith (1990). To reduce the likelihood of infection, PIT tags and radio transmitters were disinfected prior to insertion using a 0.5-percent solution of chlorohexidine diacetate (Nolvasan, Fort Dodge Animal Health, Fort Dodge, Iowa) and then rinsed twice in sterile water. Sterile surgical gloves were worn during each surgery.

To implant the tags, an incision approximately $7 \mathrm{~mm}$ long was made $5 \mathrm{~mm}$ anterior to the pelvic girdle and $3 \mathrm{~mm}$ away from and parallel to the mid-ventral line. The incision was made only deep enough to penetrate the peritoneum, using extra care so as not to damage vital organs. After the PIT tag was inserted into this incision, a shielded needle (Nipro I.V., 20-gauge $\times 5 \mathrm{~cm}$ ) was used to guide the radio transmitter's antenna through the body wall of the fish, as described by Ross and Kleiner (1982). Once the radio transmitter was in position, one to three simple, interrupted absorbable sutures (Ethicon coated vicryl braided suture 5-0, reverse cutting P-3 needle) were used to close the incision.

Following surgery, each fish was placed in a recovery bath of fresh river water until it regained equilibrium. Fish were then transferred to net pens $(1.2 \times 0.61 \times 0.61 \mathrm{~m}$ with $5 \mathrm{~mm}$ bar mesh) moored in the Klamath River near the Iron Gate Hatchery adult ladder entrance and held overnight to monitor recovery and ensure proper functioning of the radio transmitter. Fish were released after nautical twilight the following day to limit predation risk.

\section{Data Analysis}

Detections from the PIT and radio systems were used to estimate detection probability of the PIT tag detection system. Data from the radio system was reviewed to remove false positive records using methods described in Beeman and others (2008). Their methods result in retaining records that are from a transmitter released as part of the study, at a time after fish release, and with at least two detections within a 10-min period. Lastly, if a fish was detected on both the PIT and radio systems, detection of the fish at the PIT tag detection system must occur prior to the detection at the radio system. Detections from the PIT tag detection system any time after release were assumed to be true positive records. The study period used for analysis was inclusively from June 2 to August 10, 2011. This period spans the time from the date following the first release date to the last date of PIT tag detection system operation and includes $70 \mathrm{~d}$ from the last release date.

The detection probability of the primary PIT tag detection system was estimated using CormackJolly-Seber mark-recapture methods (Cormack, 1964; Jolly, 1965; Seber, 1965). Detection of a tagged fish is a function of the joint probability of survival and detection, so these parameters must be estimated separately. This was done using the "recaptures only" data type in Program Mark (White and Burnham, 1999). The analysis was based on four occasions and three periods. The occasions include release, the primary PIT detection system, and the two radio-detection systems. The intervals include release to the primary PIT tag detection system, the primary PIT tag detection system to the first radio system, and the first radio system to the second radio system. The radio systems were identical to one another and monitored the same spatial and temporal areas, so the survival between the two radio systems (the third interval) was assumed to be 1.0 and was fixed to that value for analysis. The estimate of detection probability of the primary PIT tag detection system was based on a model allowing detection probabilities to vary independently among occasions and survival probabilities to vary independently among intervals. 


\section{Detection Probabilities}

One study fish was detected by the primary PIT tag detection system and 23 were detected at the radio-telemetry systems. No fish were detected by the secondary PIT tag detection system installed on the frame net. The three fish released with only PIT tags were not detected. The study fish that was detected by the PIT tag detection system was detected once at PIT antenna 2 at 9:28:05 p.m. on June 8, 2011, and was detected a total of 18 times on the two radio systems between 1:21:46 a.m. and 1:27:45 a.m. on June 9, 2011. The 23 study fish detected by the radio systems were detected between June 7 and June 14, 2011. An additional eight fish from other studies were detected by the PIT tag detection system 1-28 times each (appendix 1). Six of the tags detected were from the 267 juvenile coho salmon tagged and released in the Shasta River by the California Department of Fish and Game (Chris Adams, written commun., November 16, 2011). Three of the nine fish detected by the PIT tag detection system were detected more than once. Of the 44 total detections, 22.7 percent were at antenna 1, 68.2 percent were at antenna 2, and 9.1 percent were at antenna 3. No fish were detected at antennas 4, 5, or 6 . The disparity in detections between antennas 1-3 and 4-6 may indicate that more fish were passing near the river left shore, detection probabilities were different among antennas, or a combination of both.

The detection probability of the PIT tag detection system was low. The capture histories of the fish implanted with both PIT and radio tags are listed in appendix 2. The estimate of the PIT tag detection system detection probability was $0.043(\mathrm{SE}=0.042)$, with a 95-percent profile-likelihood confidence interval of $0.002-0.178$. The estimate of survival from release to the PIT tag detection system was 0.535 ( $\mathrm{SE}=0.076$ ), with a 95-percent profile-likelihood confidence interval of 0.387-0.679. There was no mortality in the sample between the PIT tag detection system and the radio system, so the survival from release to the radio system was the same as the survival from release to the PIT tag detection system. All fish detected by one radio system also were detected by the other system, indicating detection probability of the first radio array was 1.0.

\section{Discussion}

The detection probability of the PIT tag detection system was much lower than expected. The system was installed in late summer 2010 when the water depth was low and the system was required to remain intact until testing with tagged fish in June 2011, when the water depth was much too deep for the in-water work required for PIT antenna installation. The system was compromised by the failure of two of the antenna power cables prior to the study period and high water levels during the study period. The antenna failures occurred between March 25, 2011, and April 7, 2011, which coincided with peak discharges. The failed antennas (antennas 5 and 6) were between the river thalweg and the shoreline. The discharge at USGS gaging station 11516530 near Iron Gate Dam was an average of 1,672.0 $\mathrm{ft}^{3} / \mathrm{s}$ (range 1,020-3,410 $\mathrm{ft}^{3} / \mathrm{s}$ ) during the study period. The low detection probability is not typical of other systems. Connolly and others (2008) estimated the system they used detected 96-100 percent of the passing tagged fish. Their system was used in a stream and consisted of three lines of six antennas $(3 \times$ 6) across a mean depth of 5-39 cm. We estimate the depth over the PIT tag detection system in this study was 1.5-1.8 $\mathrm{m}$ on June 1, 2011. That was likely the greatest depth during the study period because the river discharge decreased with time (fig. 2). We determined empirically that the read range of our PIT tag detection system was $35-41 \mathrm{~cm}$, which is similar to the $45 \mathrm{~cm}$ range reported by Connolly and others (2008). 
The estimates of survival probability of the PIT- and radio-tagged fish was slightly lower than estimates from earlier studies in the Klamath River. For example, the range in estimated survival of radio-tagged yearlong coho salmon of hatchery origin from release near Iron Gate Hatchery to the Scott River was 0.576-0.894 during studies in 2007-09 (Beeman, 2008; Beeman and Juhnke, 2009; Beeman and others, 2009) compared to 0.535 ( $\mathrm{SE}=0.076)$ from this study.

Detection probabilities of PIT antenna systems are affected by several factors. These include ambient electromagnetic fields, changes in water temperature and conductivity, presence of more than one tag in the antenna field at a time, and distance between the tag and the antenna (Zydlewski and others, 2006). Of these, the PIT tag detection system we evaluated likely was affected only by the distance between the tag and the antenna. The read ranges of test tags used at the pass-by antennas were 35-41 cm and the read ranges of the pass-through antennas were slightly larger. These read ranges are consistent with the performance of other systems (Connolly and others, 2008). It is also unlikely that tag detections were hindered by multiple tags being present at an antenna at the same time, given the small number of tagged fish from this and other studies in the area. Effects of changes in water temperature or conductivity also are unlikely in this case because the receiver we used was a self-tuning type. Water depth over the antennas is known to negatively affect detection probability of juvenile salmonids (that is, non-benthic fish) due to the relatively small read range of PIT tag detection systems (Connolly and others, 2008). Water depth over the antennas likely would be less of a problem for fish traveling close to the river bottom, such as adult salmonids. We estimate that the water depth over the antennas was 1.5$1.8 \mathrm{~m}$, which is several times the read ranges we measured. Connolly and others (2008) noted a difference in PIT tag detection system detection probability between data collected at water depths less than $16 \mathrm{~cm}$ and at water depths greater than $16 \mathrm{~cm}$.

Detection probabilities of PIT tag detection systems also vary with the design. Pass-by antennas have shorter read ranges than pass-through antennas because pass-by antennas are laid flat on the substrate and fish can pass by only on one side. However, pass-by antennas pose less of an obstruction to water and debris passage than pass-through antennas, and are more resistant to damage from these sources (Zydlewski and others, 2006). We chose to design the system as a series of pass-by antennas for this reason. The addition of the pass-through antennas near one shoreline was opportunistic due to the damage two of the original antennas and the high water present prior to release of the fish.

The results of this study suggest a series of PIT antennas placed in a shallower area, or a similar system used during a lower river stage height, would be required to achieve higher detection probabilities for studies of juvenile salmonids in the Klamath River. Antennas placed across all or part of the river in a series like the system described by Connolly and others (2008) could increase detection probability over a single line of detectors. The expected detection probability of a system of multiple detection arrays spanning the river can be estimated with the equation

$$
P_{\text {system }}=1-\left(1-P_{\text {array }}\right)^{N},
$$

where $\mathrm{N}$ is the number of individual detection arrays spanning the river. If the single-system detection probability from this study were assumed (0.043), the expected total system detection probabilities for PIT-tagged juvenile coho salmon under conditions during this study would be 0.084 for two systems, 0.124 for three systems, and 0.161 for four systems. The two largest uncertainties in deploying such a system in the Klamath River would be system damage from high discharge or debris loads, and the water depth over the antennas. Antennas of a lower-profile design, such as the flat-plate design described by Nunnallee and others (1998), or partially submerging the antennas into the substrate may reduce damage. Deployment sites expected to minimize water depth over the antennas during the desired study period also would be required to improve detections of juvenile salmonids. 
The use of an active telemetry system to evaluate the PIT detection system was efficient. We used the radio-telemetry system to estimate detection probability of the PIT detection system because the radio-telemetry system had been shown to have high detection probability in the study area (Beeman and others, 2008). In this study, the detection probability of the upstream radio array was 1.0. Use of a system with a high detection probability increases the information used from each fish and decreases the number of fish needed. We could have used a secondary PIT detection system to estimate the detection probability of the primary PIT detection system evaluated in this study, but if the detection probability of the secondary system was similar to that of the primary system, we likely would have detected only $23 * 0.043=1$ PIT-tagged fish on the secondary array rather than the 23 detected at the radio-telemetry detection system, resulting in little information with which to evaluate the primary system. An estimated total of 23/0.043 $=538$ PIT-tagged fish would have been required to achieve the same precision in detection probability as we achieved by releasing 43 PIT-tagged and radio-tagged fish if a secondary PIT detection system were used rather than the radio-telemetry detection system.

In summary, the PIT detection system evaluated in 2011 was damaged during high river discharges and the detection probability was lower than expected. Damage from high water velocities could be mitigated in future deployments by using antennas with a low-profile design, or by burying the antennas into the substrate. The detection probabilities of juvenile coho salmon likely were affected negatively by the high river stage during the study period. Detection probabilities of all fishes could be increased by using a series of antenna systems spanning the river and those of pelagic fish can be expected to increase under conditions of shallow water over the antennas. PIT antennas near the river bottom may work well for other species or life stages present close to the river bottom, such as adult salmonids.

\section{Acknowledgments}

We thank the California Department of Fish and Game staff at the Iron Gate Fish Hatchery for providing fish and space for this study. Chris Adams of the California Department of Fish and Game assisted with PIT tag detection system maintenance, and Philip Haner of the U.S. Geological Survey designed and oversaw the installation of the radio-telemetry detection system. We also thank Darcy Derry for allowing the primary PIT tag detection system to be installed on private land. The document was improved by review comments from Bill Muir and Pat Connolly. The Bureau of Reclamation funded the study under interagency acquisition number R10PG20183.

\section{References Cited}

Adams, N.S., Rondorf, D.W., Evans, S.D., and Kelley, J.E., 1998, Effects of surgically and gastrically implanted radio transmitters on growth and feeding behavior of juvenile Chinook salmon:

Transactions of the American Fisheries Society, v. 127, p.128-136.

Beeman, J.W., 2008, Summary of survival data from juvenile coho salmon in the Klamath River, Northern California, 2007: U.S. Geological Survey Open-File Report 2008-1022, 6 p. (Also available at http://pubs.usgs.gov/of/2008/1022/.)

Beeman, J.W., and Juhnke, S.D., 2009, Summary of survival data from juvenile coho salmon in the Klamath River, Northern California, 2009: U.S. Geological Survey Open-File Report 2009-1270, 8 p. (Also available at http://pubs.usgs.gov/of/2009/1270/.) 
Beeman, J.W., Juhnke, S.D., and Hansel, H.C., 2009, Summary of survival data from juvenile coho salmon in the Klamath River, northern California, 2008: U.S. Geological Survey Open-File Report 2009-1019, 6 p. (Also available at http://pubs.usgs.gov/of/2009/1019/.)

Beeman, J.W., Juhnke, S., Stutzer, G., and Hetrick, N., 2008, Survival and migration behavior of juvenile coho salmon in the Klamath River relative to discharge at Iron Gate Dam, 2007: U.S. Geological Survey Open-File Report 2008-1332, 72 p. (Also available at http://pubs.usgs.gov/of/2008/1332/.)

Connolly, P.J., Jezorek, I.G., Martens, K.D., and Prentice, E.F., 2008, Measuring the performance of two stationary interrogation systems for detecting downstream and upstream movement of PIT-tagged salmonids: North American Journal of Fisheries Management, v. 28, p. 402-417.

Cormack, R.M., 1964, Estimates of survival from the sighting of marked animals: Biometrika, v. 51, no. 3/4, p. 429-438.

Hewitt, D.A., Janney, E.C., Hayes, B.C., and Shively, R.S., 2010, Improving inferences from fisheries capture-recapture studies through remote detection of PIT tags: Fisheries, v. 35, p. 217-231.

Jolly, G.M., 1965, Explicit estimates from capture-recapture data with both death and immigrationstochastic model: Biometrika, v. 52, no. 1/2, p. 225-247.

Nunnallee, E.P., Prentice, E.F., Jonasson, B.F., and Patten, W., 1998, Evaluation of a flat-plate PIT tag interrogation system at Bonneville Dam: Aquacultural Engineering, v. 17, p. 261-272.

Prentice, E.F., Flagg, T.A., and McCutcheon, C.S, 1990, Feasibility of using implantable passive integrated transponder (PIT) tags in salmonids: American Fisheries Society Symposium 7, p. 317322.

Ross, M. J., and Kleiner, C. F., 1982, Shielded-needle technique for surgically implanting radiofrequency transmitters in fish: Progressive Fish Culturist, v. 44, p. 41-43.

Seber, G.A.F., 1965, A note on the multiple-recapture census: Biometrika, v. 52, no. 1/2, p. 249-259.

Stutzer, G.M., Ogawa, J., Hetrick, N.J., and Shaw, T., 2006, An initial assessment of radio telemetry for estimating juvenile coho salmon survival, migration behavior, and habitat use in response to Iron Gate Dam discharge on the Klamath River, California: Arcata, California, U.S. Fish and Wildlife Service, Arcata Fisheries Technical Report Number TR2006-05.

Summerfelt, R.C. and Smith, L.C., 1990, Anesthesia, surgery, and related techniques, in Schreck, C.B. and Moyle, P.B., Methods for fish biology: Bethesda, Maryland: American Fisheries Society, p. 213263.

White, G.C., and Burnham, K.P., 1999, Program MARK—-survival estimation from populations of marked animals: Bird Study, v. 46 (supplement), p. 120-138.

Williams, J.G., Smith, S.G., and Muir, W.D., 2001, Survival estimates of downstream migrant yearling juvenile salmonids through the Snake and Columbia rivers hydropower system, 1966-1980 and 19931999: North American Journal of Fisheries Management, v. 21, p. 310-317.

Wright, K., Juhnke, S., Hansel, H., Beeman, J., Hetrick, H., 2011, Effect of dietary salt on migration and survival of yearling steelhead produced at Iron Gate Hatchery, Klamath River, 2009: U.S. Fish and Wildlife Service Arcata Fisheries Technical Report TR2011-15.

Zydlewski, J.B., Horton, G., Dubreuil, T., Letcher, B., Casey, S., and Zydlewski, J., 2006, Remote monitoring of fish in small streams-A unified approach using PIT tags: Fisheries, v. 31, no. 10, p. 492-502. 


\section{Appendix 1. Detections of PIT Tags from Other Studies.}

[These data are from the PIT tag detection system installed at Klamath River kilometer 252.7 and operated from June 1 to August 10, 2011]

\begin{tabular}{|c|c|c|c|c|c|}
\hline Tag identifier & $\begin{array}{c}\text { Detection time } \\
\text { (mm/dd/yyyy hh:mm:ss) }\end{array}$ & $\begin{array}{c}\text { Antenna } \\
\text { No. }\end{array}$ & Tag identifier & $\begin{array}{l}\text { Detection } \\
\text { time }\end{array}$ & $\begin{array}{c}\text { Antenna } \\
\text { No. }\end{array}$ \\
\hline 3D6.00084E2AA1 & 08/06/2011 01:56:20 PM & 3 & 3D9.1C2D2836A8 & 06/05/2011 06:59:03 PM & 2 \\
\hline 3D9.1C2D18D911 & 07/11/2011 05:16:43 PM & 1 & 3D9.1C2D2836A8 & 06/05/2011 07:04:09 PM & 2 \\
\hline 3D9.1C2D18D911 & 07/11/2011 05:16:45 PM & 2 & 3D9.1C2D2836A8 & 06/05/2011 07:09:11 PM & 2 \\
\hline 3D9.1C2D18D911 & 07/11/2011 05:25:05 PM & 2 & 3D9.1C2D2836A8 & 06/05/2011 07:14:13 PM & 2 \\
\hline 3D9.1C2D18D911 & 07/11/2011 05:25:07 PM & 1 & 3D9.1C2D2836A8 & 06/05/2011 07:14:56 PM & 1 \\
\hline 3D9.1C2D18D911 & 07/11/2011 05:37:23 PM & 2 & 3D9.1C2D2836A8 & 06/05/2011 07:19:45 PM & 2 \\
\hline 3D9.1C2D18D911 & 07/11/2011 05:40:18 PM & 1 & 3D9.1C2D2836A8 & 06/05/2011 07:25:07 PM & 2 \\
\hline 3D9.1C2D18D911 & 07/11/2011 05:46:18 PM & 2 & 3D9.1C2D2836A8 & 06/05/2011 07:30:08 PM & 2 \\
\hline 3D9.1C2D18D911 & 07/11/2011 05:48:26 PM & 1 & 3D9.1C2D2836A8 & 06/05/2011 07:36:21 PM & 2 \\
\hline 3D9.1C2D18DD6D & 06/25/2011 09:45:46 AM & 1 & 3D9.1C2D2836A8 & 06/05/2011 07:41:45 PM & 2 \\
\hline 3D9.1C2D18DD6D & 06/25/2011 09:54:46 AM & 2 & 3D9.1C2D2836A8 & 06/05/2011 07:46:59 PM & 2 \\
\hline 3D9.1C2D18E559 & 06/29/2011 02:27:30 AM & 2 & 3D9.1C2D2836A8 & 06/05/2011 07:52:00 PM & 2 \\
\hline 3D9.1C2D1FE53A & 07/21/2011 05:22:08 AM & 3 & 3D9.1C2D2836A8 & 06/05/2011 07:59:23 PM & 2 \\
\hline 3D9.1C2D282416 & 06/23/2011 03:38:31 AM & 3 & 3D9.1C2D2836A8 & 06/05/2011 08:05:18 PM & 2 \\
\hline 3D9.1C2D2836A8 & 06/05/2011 06:17:31 PM & 2 & 3D9.1C2D2836A8 & 06/05/2011 08:16:29 PM & 2 \\
\hline 3D9.1C2D2836A8 & 06/05/2011 06:25:25 PM & 2 & 3D9.1C2D2836A8 & 06/05/2011 08:21:33 PM & 2 \\
\hline 3D9.1C2D2836A8 & 06/05/2011 06:30:43 PM & 2 & 3D9.1C2D2836A8 & 06/05/2011 08:29:58 PM & 1 \\
\hline 3D9.1C2D2836A8 & 06/05/2011 06:32:00 PM & 1 & 3D9.1C2D2836A8 & 06/05/2011 08:30:32 PM & 2 \\
\hline 3D9.1C2D2836A8 & 06/05/2011 06:38:13 PM & 2 & 3D9.1C2D2836A8 & 06/05/2011 08:42:42 PM & 1 \\
\hline 3D9.1C2D2836A8 & 06/05/2011 06:43:33 PM & 2 & 3D9.1C2D2836A8 & 06/05/2011 08:50:38 PM & 1 \\
\hline 3D9.1C2D2836A8 & 06/05/2011 06:48:33 PM & 2 & 3D9.1C2D2869C7 & 06/14/2011 11:40:00 PM & 3 \\
\hline 3D9.1C2D2836A8 & 06/05/2011 06:53:44 PM & 2 & & & \\
\hline
\end{tabular}




\section{Appendix 2. Capture Histories of PIT- and Radio-Tagged Yearling Coho Salmon from Iron Gate Hatchery Used to Evaluate a PIT Detection System in the Klamath River, 2011.}

[The four occasions are release, the primary PIT detection system, and each of two identical radio detection systems. A ' 1 ' in a column indicates detection (or release) and ' 0 ' indicates no detection]

\begin{tabular}{cc}
\hline $\begin{array}{c}\text { Encounter } \\
\text { history }\end{array}$ & $\begin{array}{c}\text { Observed } \\
\text { count }\end{array}$ \\
\hline 1111 & 1 \\
1011 & 22 \\
1000 & 20 \\
\hline
\end{tabular}


Publishing support provided by the U.S. Geological Survey

Publishing Network, Tacoma Publishing Service Center

For more information concerning the research in this report, contact the Director, Western Fisheries Research Center U.S. Geological Survey

6505 NE 65th Street

Seattle, Washington 98115

http://wfrc.usgs.gov/ 
